\title{
Elektrostatik ekstrüzyon tekniği ile kapsüllenmiş bazı aroma maddelerinde sıcaklığın depolama stabilitesi üzerine etkisi
}

\author{
Effect of temperature on storage stability of some flavor compounds encapsulated by \\ electrostatic extrusion technique
}

\author{
Hüseyin KARAKAYA ${ }^{1, a}$, Murat YILMAZTEKİN*1,b

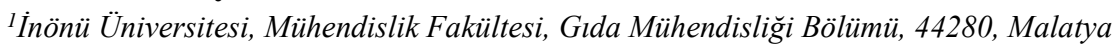

\begin{tabular}{|c|c|c|}
\hline - Geliş tarihi / Received: 09.04.2021 & • Düzeltilerek geliş tarihi / Received in revised form: 17.05 .2021 & • Kabul tarihi / Accepted: 13.06 .2021 \\
\hline
\end{tabular}

\begin{abstract}
Öz
Aroma maddeleri başta sıcaklık olmak üzere çeşitli depolama koşullarından kolaylıkla etkilenebilmektedir. Bu çalışmada, elektrostatik ekstrüzyon tekniği ile üretilen aroma mikrokapsüllerinin depolama sürecindeki termal stabilitelerinin incelenmesi amaçlanmıştır. $8 \mathrm{kV}$ elektrik potansiyeli altında benzaldehit, izoamil asetat ve mentol yüklü aljinat mikrokapsülleri üretilmiş ve kullanılan aroma oranına $(\% 10-50, a / a)$ bağlı olarak enkapsülasyon etkinlikleri belirlenmiştir. Serbest ve enkapsüle haldeki aroma maddeleri 90 gün süreyle $-18{ }^{\circ} \mathrm{C},+4{ }^{\circ} \mathrm{C}$ ve $+25{ }^{\circ} \mathrm{C}$ 'de karanlıkta muhafaza edilmiștir. 30 günlük periyotlarla örnekler alınmış ve kalan aroma miktarları gaz kromatografisi-kütle spektrometresi (GC-MS) kullanılarak belirlenmiştir. Liyofilize mikrokapsüllerin ortalama çaplarının 668.2-846.3 $\mu \mathrm{m}$ arasında değiştiği hesaplanmıştır. Denemesi yapılan tüm aroma maddeleri arasında en yüksek enkapsülasyon etkinliğine \%10 aroma maddesi içeren bileşimde ulaşılırken; benzaldehit, izoamil asetat ve mentol için enkapsülasyon etkinlikleri sırasıyla \%97.2, \%98.5 ve \%93.4 olarak bulunmuştur. Tüm denemelerde depolama sıcaklığındaki artışa bağlı olarak alıkonan aroma miktarında azalmalar yaşandığı belirlenmiştir. Ancak enkapsüle aroma maddelerinde gözlenen kayıp serbest hallerine göre oldukça sınırlı kalmıştır. 90 günlük depolama periyodu sonunda en yüksek aroma içeriği $-18^{\circ} \mathrm{C}^{\prime}$ de depolanmış enkapsüle aroma maddelerinde tespit edilirken; en fazla kaybın $+25^{\circ} \mathrm{C}^{\prime}$ de depolanmış serbest aroma maddelerinde yaşandığ 1 belirlenmiştir. Elektrostatik ekstrüzyon ile enkapsülasyonun başta aroma maddeleri olmak üzere uçucu bileşiklerin depolama stabilitelerinin arttrrılmasında önemli bir uygulama olabileceği düşünülmektedir.
\end{abstract}

Anahtar kelimeler: Aroma, Elektrostatik ekstrüzyon, Enkapsülasyon, Stabilite

\begin{abstract}
Aroma compounds can be easily affected by various storage conditions, especially temperature. In this study, it was aimed to investigate thermal stability of aroma microcapsules produced by electrostatic extrusion technique during storage process. Benzaldehyde, isoamyl acetate and menthol loaded alginate microcapsules were produced under $8 \mathrm{kV}$ electrical potential and encapsulation efficiencies were determined depending on aroma concentration $(10-50 \%, w / w)$ used. Free and encapsulated forms of aroma compounds were stored in dark at $-18{ }^{\circ} \mathrm{C},+4^{\circ} \mathrm{C}$ and $+25^{\circ} \mathrm{C}$ for 90 days. Samples were taken at time intervals of 30 days and remained amounts of the aroma was determined by using gas chromatographymass spectrometry (GC-MS). It was measured that mean diameters of lyophilized microcapsules were ranged between 668.2-846.3 $\mu \mathrm{m}$. While the highest encapsulation efficiency was reached in that formulation containing 10\% aroma for all tested substances, the efficiencies were found $97.2 \%, 98.5 \%$ and $93.4 \%$ for benzaldehyde, isoamyl acetate and menthol, respectively. In all trials, it was determined that there was a decrease in the amount of aroma retained due to increase in storage temperature. However, the loss observed in the encapsulated aroma compounds was rather limited compared to their free form. In the end of 90 days storage period, the highest aroma content was detected in encapsulated aroma substances stored at $-18{ }^{\circ} \mathrm{C}$, while the highest loss was determined on the free forms stored at $+25^{\circ} \mathrm{C}$. It is thought that encapsulation by electrostatic extrusion can be an important application in increasing storage stability of volatile substances, particularly aroma compounds.
\end{abstract}

Keywords: Aroma, Electrostatic extrusion, Encapsulation, Stability

\footnotetext{
${ }^{* b}$ Murat YILMAZTEKIN; murat.yilmaztekin@inonu.edu.tr; Tel: (0422) 37747 84; orcid.org/0000-0002-5667-9169

${ }^{a}$ orcid.org/0000-0002-6311-473X
} 


\section{Giriş}

Aroma, gıdalara sağladığı tat ve koku nedeniyle gidaların kabul edilebilirliği ve kalitesi üzerine etkili bir faktördür (Byun vd., 2010). Aroma bileşiklerinin pek çoğu sıvı ya da gaz formda bulunduğu gibi bazıları da (mentol ve vanilin) katı halde bulunabilmektedir (Zuidam ve Heinrich, 2010). Üretim, paketleme veya depolama süreçlerinde aroma bileşenlerinde kayıplar ya da değişimler gözlenebilmektedir (Byun vd., 2010). Özellikle uçucu yağlar oldukça hassas olup; birtakım çevresel etkilere (sıcaklık, 1şık, oksijen, nem vb.) maruz kaldıklarında kolaylıkla farklı bir bileşene indirgenmekte veya dönüşmektedir (Da Veiga vd., 2019; Chenni vd., 2020). Enkapsülasyon, aroma maddelerinin korunmas1, istenmeyen kokuların maskelenmesi, termal ve oksidatif stabilitesinin arttırılması, yüksek uçuculuğunun sınırlandırılması, hızlı salınımının kontrol altına alınması, biyoyararlılığının ve gida sistemlerinde kullanımının arttırılması açısından en başarılı yoldur (Saifullah vd., 2019). Mikroenkapsülasyon tanım olarak hedef maddenin bir kabuk materyali merkezine alınarak ince kapsüller halinde kaplanması işlemidir (Hu vd., 2020). Bu sayede aroma maddelerinin daha uzun süreler gıdada alıkonulması, gıdayla aroma maddesi arasında istenmeyen etkileşimlerin önlenmesi ve bileşiğin 1 ş1k etkileşimli reaksiyonlardan korunması sağlanabilmektedir (Sun vd., 2013). Ayrica sivi formdaki aroma maddeleri enkapsülasyon ile toz forma sokularak endüstrideki kullanım alanı arttırılabilmektedir (Garcia vd., 2012). Tüm bunlar için mikroenkapsülasyonda kullanılacak kabuk materyalin merkez içerik ile reaksiyon vermemesi, toksik olmaması, düşük nem absorbsiyonu göstermesi, kaplama özelliği ve akışkanlığının iyi olmasi gerekmektedir (Zhu vd., 2018).

Enkapsülasyon yöntemleri temelinde mekanik (örn; püskürtmeli kurutma), kimyasal (örn; polikondensasyon, in situ polimerizasyon) ve fizikokimyasal (örn; iyonik jelasyon) olmak üzere 3 gruba ayrılmaktadır (Jyothi vd., 2010; Sahlan ve Rahman, 2017). Aroma maddelerinin mekanik enkapsülasyonunda kullanılan en yaygın yöntem püskürtmeli kurutmadır (Sun vd., 2013). Ancak aroma maddeleri düşük kaynama noktalarına sahip olduğundan, uygulanan yüksek sicaklık buharlaşmaya bağlı işlem kaybını arttırmaktadır (Sun vd., 2013; Renu ve Zehra, 2015). Kimyasal enkapsülasyon işlemlerinde ise asit klorit veya formaldehit gibi bileşiklerden faydalanılarak bir kabuk materyal üretilmekte ve bu kabuk materyal ile hedef bileşen polimerleştirilmektedir (Jyothi vd., 2010). Bu uygulamalarda kullanılan bileşikler çoğunlukla toksik ve/veya yanıcı nitelikte olduğundan gerek tüketici sağlığ1 gerekse uygulama açısından risk yaratmaktadır. Çeşitli biyopolimerler arasinda kimyasal stabilite, $\mathrm{pH}$ duyarlılı̆ğ, su ve gazlara karşı güçlü jel bariyer oluşturma yeteneği ve iştah düzenlemedeki biyolojik işlevselliği açısından aljinat eşsiz bir yer tutmaktadır (Volic vd., 2018). Doğal anyonik bir polimer olup düşük maliyetli olması, biyouyumluluğu ve toksik olmaması gibi nedenlerle biyoteknoloji araştırmalarında sıklıkla kullanılmaktadır. Aljinat, kalsiyum iyonları $\left(\mathrm{Ca}^{++}\right)$ gibi çok değerli katyonlarla iyonik bağ yapma yeteneğine sahiptir (Benavides vd., 2016). İyonik jelasyonda kaplanmak istenen bileşen aljinat çözeltisi ile karıştırılır ve $\mathrm{Ca}^{++}$iyonu içeren çözeltiye damlatılır. Basit ve hızlı bir yöntem olmasına rağmen polimer çözeltisinin yüzey gerilimi, küçük ve homojen damlacıklar üretilmesini kısıtlayan bir faktördür (Nikoo vd., 2018). Aljinat tabanlı çeşitli enkapsülasyon yöntemlerinde üretilen kapsül boyutları 2000 $\mu$ m'ye kadar ulaşabilmektedir. Kapsül boyutlarının çok büyük olması içine katıldığı gıdanın gerek tekstürel gerekse duyusal niteliklerini olumsuz yönde etkilemesi nedeniyle istenilen bir durum değildir (Istenic vd., 2015). Bu nedenle, iyonik jelasyon yöntemi başta elektrostatik ekstrüzyon olmak üzere çeşitli ek uygulamalarla modifiye edilerek kullanılmaktadır. Elektrostatik ekstrüzyon tekniğinde iğne ucu ve altındaki sertleştirme çözeltisi arasına yüksek voltaj uygulanır. Voltaj, iğne ucundaki damla büyümeden (kendi ağırlığıyla düşmesini bekletmeden) oluşan damlacığın hemen altında yer alan $\mathrm{CaCl}_{2}$ çözeltisine çekilmesini sağlar (Klokk ve Melvik, 2002). Bu sayede daha küçük ve yeknesak kapsüller üretilebilmektedir (Manojlovic vd., 2008).

Bu çalışmada elektrostatik ekstrüzyon yöntemi ile enkapsüle edilmiş bazı aroma maddelerinin depolama süresince 1 sil stabilitelerinin araştırılması amaçlanmıştır. Çalışmada kapsüllenecek aroma maddeleri olarak farkl1 fiziksel ve kimyasal yapıları temsilen benzaldehit $\left(25^{\circ} \mathrm{C}\right.$ 'de sivı, aldehit), izoamil asetat $\left(25^{\circ} \mathrm{C}^{\prime} \mathrm{de}\right.$ sivi, ester) ve mentol $\left(25^{\circ} \mathrm{C}\right.$ ' de kat1, terpenik alkol) seçilmiştir. Aroma maddeleri yüksek voltaj altında Ca-aljinat ile kaplanmış ve mikroskop altında elde edilen mikrokapsüllerin morfolojileri incelenmiştir. Farklı sıcaklıklarda 90 gün boyunca depolanan mikrokapsüllerin sahip olduğu aroma miktarları GC-MS ile belirlenmiştir. Mikrokapsül içinde tutuklu örnekler ile serbest haldeki aroma örnekleri kıyaslanarak farklı depolama 
sıcaklıklarında aroma maddesi miktarındaki zamana bağlı değişim incelenmiştir.

\section{Materyal ve metot}

\subsection{Materyal}

Enkapsülasyon denemelerinde kullanılan benzaldehit (\%99.5) Roth, (Almanya) firmasindan, izoamil asetat (\%99) ve mentol (\%99) ise SigmaAldrich (MO, ABD) firmasından temin edilmiştir. Tween 80 , sodyum aljinat, $\mathrm{CaCl}_{2} \cdot 2 \mathrm{H}_{2} \mathrm{O}$ (\%99), sodyum sitrat (\%99) ve diklorometan (\%99.8) yine Sigma-Aldrich (MO, ABD) firmasindan temin edilmiştir.

\subsection{Elektrostatik ekstrüzyon ile enkapsülasyon}

Kalsiyum aljinat (Ca-aljinat) mikrokapsüllerinin üretimi emülsifikasyon, elektrostatik ekstrüzyon ve jelleşme olmak üzere 3 aşamada gerçekleştirilmiştir. İlk aşamada sodyum aljinat, konsantrasyonu $0.02 \mathrm{~g} / \mathrm{mL}$ olacak şekilde distile su içerisinde çözündürülmüştür. Sodyum aljinat çözeltisi içerisine son konsantrasyon \%10 olacak şekilde Tween 80 ve \%10-50 (a/a) aras1 değişen oranlarda aroma maddesi ilave edilmiştir. Oda sicaklığında sivi formda olan benzaldehit ve izoamil asetat doğrudan; kristal haldeki mentol ise $45{ }^{\circ} \mathrm{C}$ eritildikten sonra ilave edilmiştir. Çözelti Ultra-turrax T25 (IKA, Almanya) mekanik karıştırıcıda $10000 \mathrm{~d} / \mathrm{d}$ hızla 2 dk karıştırılarak stabil emülsiyonlar elde edilmiştir. İkinci aşamada Balanc vd. (2016) tarafından belirtilen yöntemde küçük iyileştirmeler yapılarak aroma maddesi içeren aljinat damlacıkları üretilmiştir. Mikroenkapsülasyon işlemi VAR V1 (Nisco Engineering Inc., İsviçre) elektrostatik ekstrüzyon enkapsülatörü ve bu cihaza entegre Pump 11 (Harvard Apparatus, ABD) enjektör pompas1 kullanılarak gerçekleştirilmiştir (Şekil 1). 50 mL'lik enjektör içerisine yerleştirilen emülsiyon $25.2 \mathrm{~mL} / \mathrm{sa}$ hızla enkapsülatör içerisine pompalanmıştır. Emülsiyon çelik iğne bir uçtan (iç çap $0.40 \mathrm{~mm}$, diş çap $0.70 \mathrm{~mm}$ ) sürekli karıştırılan $100 \mathrm{~mL} \mathrm{CaCl}{ }_{2}$ çözeltisi $(0.015 \mathrm{~g} / \mathrm{mL})$ içerisine yeknesak damlatılmıştır. Damlacıkların düşme yüksekliği $4 \mathrm{~cm}$ olarak ayarlanmış ve işlem 8 $\mathrm{kV}$ 'luk sabit elektrostatik potansiyel altında gerçekleştirilmiştir. Toplama kabındaki sertleştirme çözeltisi içerisine $25 \mathrm{~mL}$ emülsiyon damlatılana kadar mikroenkapsülasyon işlemi devam ettirilmiştir. Enjektörde kalan kısım serbest aroma analizi için ayrılmıştır. Son olarak jelleşmenin sağlanabilmesi için üretilen boncuklar 60 dk karıştırma olmaksızın $\mathrm{CaCl}_{2}$ çözeltisi içerisinde bekletilmiştir. Kabuk kısmı sertleşen boncuklar filtre kağıdı ile süzülmüş ve distile suyla yıkanmıştır.

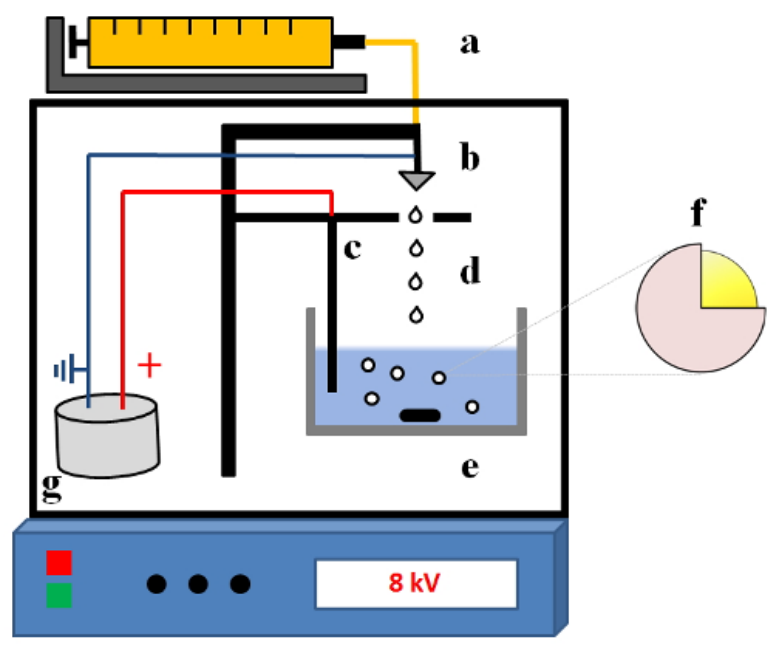

Şekil 1. Elektrostatik ekstrüzyon ile enkapsülasyon işleminin şematik gösterimi. a) Enjektör ve pompa sistemi, b) Çelik iğne, c) Elektrot ve orifiz, d) Üretilen damlacıklar, e) Manyetik karıştırıcılı sertleştirme $\left(\mathrm{CaCl}_{2}\right)$ çözeltisi, f) Aroma yüklü mikrokapsül boncuğu, g) Yüksek voltaj güç kaynağ1

Mevcut suyun uzaklaştırılması için elde edilen boncuklar $-20{ }^{\circ} \mathrm{C}^{\prime} \mathrm{de} \quad 24$ saat bekletilmiş ve liyofilizatörde (Armfield, İngiltere) $-50{ }^{\circ} \mathrm{C}$ 'de 18 saat dondurarak kurutulmuştur. Her üretimden seçilen 30 adet kuru boncuk XTL-3 400 D mikroskop (Leica, Almanya) altında incelenmiştir. Okülere entegre DC 300 kamera (Leica, Almanya) yardımıyla görüntüler alınmış ve ortalama kapsül boyutları IM 1000 (Leica, Almanya) yazılımı ile ölçülmüştür. Asimetrik boncuklarda yatay ve dikey yönlü uzunlukların ortalaması alınarak ölçüm yapılmıştır (Levic vd., 2015).

\subsection{Enkapsülasyon etkinliği ve depolama}

Stabilite denemeleri öncesi üretilen mikrokapsüllerin içerdiği aroma miktarları ve buna bağl1 olarak enkapsülasyon etkinlikleri belirlenmiştir. Enkapsülasyon etkinliği (EE) aşağıda verilen denklem 1'e göre hesaplanmıştır (Nikoo vd., 2018). Denklemde emülsiyon içerisinde kullanılan başlangıç aroma miktarı $\mathrm{M}_{0}$ (g) olarak ifade edilirken, mikrokapsüller içerinde alıkonan aroma miktarı $\mathrm{M}_{1}(\mathrm{~g})$ olarak belirtilmiştir.

$\mathrm{EE}(\%)=\frac{M_{1}}{M_{0}} \times 100$

Depolama denemeleri için, daha yüksek enkapsülasyon etkinliği sağlayan aroma konsantrasyonu kullanılarak yeni üretimler 
yapılmıştır. Her bir aroma maddesinin hem serbest ve hem de enkapsüle formunu temsil edecek şekilde, vida kapaklı cam deney tüpleri içerisine 10 g örnek tartılmıştır. Örnekler $-18{ }^{\circ} \mathrm{C},+4{ }^{\circ} \mathrm{C}$ ve +25 ${ }^{\circ} \mathrm{C}$ 'de 90 gün boyunca karanlıkta muhafaza edilmiştir. Depolama sürecinde her 30 günde bir örnekleme yapılarak kalan aroma miktarındaki değişim periyodik olarak takip edilmiştir.

\subsection{Ekstraksiyon ve miktar tayini}

Mikrokapsülde tutuklu bulunan aroma miktarının tespiti için öncelikle kapsül içeriğinin salınımı sağlanmıştır. Aroma salınımı, Gandomi vd. (2016) tarafindan belirtilen yöntemde küçük iyileştirmeler yapılarak gerçekleştirilmiştir. Bir cam şişe içerisine $0.5 \mathrm{~g}$ mikrokapsül tartılmış ve üzerine $40 \mathrm{~mL} 0.06$ M sodyum sitrat çözeltisi eklenmiştir. Karışım oda sıcaklığında $5 \mathrm{dk}$ boyunca sert şekilde karıştırılmış ve sodyum sitrat etkisiyle boncuk yapısının parçalanması sağlanmıştır. Ortama $5 \mathrm{~mL}$ diklorometan (\%99.8) ilave edilerek serbest kalan aroma maddeleri ekstrakte edilmiştir. $15 \mathrm{dk}$ aralıklı karıştırmadan sonra şişe muhteviyatı ayırma hunisine aktarılmış ve organik fazın ayrılması sağlanmıştır. Ekstraktlar, $0.45 \mu \mathrm{m}$ 'lik enjektör filtresinden geçirilerek amber renkli vialler içerisine alınmıştır.

Miktar tayini Shimadzu QP 2010 Plus Gaz Kromatografisi (Shimadzu, Japonya) ve cihaza entegre MS-QP 2010 kütle spektrometresi kullanılarak gerçekleştirilmiştir. AOC-20i/20s otoörnekleyici yardımıyla vialden $1 \mu \mathrm{L}$ örnek alınmış ve DB-WAX (J\&W Scientific, CA, ABD) kaynaşı silika kapiler kolon $(60 \mathrm{~m} \times 0.25 \mathrm{~mm} \times 0.25$ $\mu \mathrm{m})$ içerisine enjekte edilmiştir. Taşıyıcı gaz olarak \%99.99 saflıkta helyum gazı kullanılmış ve akış hızı $1 \mathrm{~mL} / \mathrm{dk}$ olacak şekilde ayarlanmıştır. Fırın sıcaklığı programlamas $140^{\circ} \mathrm{C}$ 'de başlayarak $5 \mathrm{dk}$ bekleme, ardından $8{ }^{\circ} \mathrm{C} / \mathrm{dk}$ artışla $240{ }^{\circ} \mathrm{C}$ 'ye çıkış ve $240{ }^{\circ} \mathrm{C}$ 'de $10 \mathrm{dk}$ bekleme şeklinde uygulanmıştır. İyon kaynağı $200^{\circ} \mathrm{C}$ 'ye; enjeksiyon portu ve transfer hattı sicaklığ $250{ }^{\circ} \mathrm{C}$ 'ye ayarlanmıştır. İyonlaşmanın sağlanması için $70 \mathrm{eV}$ enerji uygulanmıştır. Kütle spektrumu 1 tarama/sn tarama hızıyla, $30-450 \mathrm{~m} / \mathrm{z}$ arası iyonlar için oluşturulmuştur. Miktar tayini için enkapsülasyonda kullanılan yüksek saflıktaki $(\geq \% 99)$ aroma maddeleri standart olarak kullanılmış ve 4 noktalı kalibrasyon grafiğinden yararlanılarak hesaplamalar gerçekleştirilmiştir. Benzaldehit, izoamil asetat ve mentole ait kalibrasyon grafiklerinin $\mathrm{R}^{2}$ değerleri sırasıyla $0.9986,0.9967$ ve 0.9992 olarak hesaplanmıştır.

\subsection{Istatistiksel analizler}

Denemeler üç tekrar halinde gerçekleştirilmiş olup sonuçlar ortalama \pm standart sapma şeklinde ifade edilmiştir. Verilerin istatistiksel değerlendirmesi SPSS 16.0 (SPSS Inc., IL, ABD) paket program1 kullanılarak gerçekleştirilmiştir. Sonuçlar arasındaki farkların önem düzeyi $(p<0.05)$ tek yönlü varyans analizinde Tukey çoklu karşılaş̧ırma testleri ile belirlenmiş̧ir.

\section{Bulgular ve tartışma}

\subsection{Kapsül morfolojisi ve enkapsülasyon etkinliği}

Mikrokapsüllerin kurutulmasındaki amaç kapsül içeriğindeki suyun uzaklaştırılarak daha dayanıklı bir ürün elde edilmesidir (Chenni vd., 2020). Mikrokapsüllerin liyofilizasyon öncesi ve sonras1 şekilsel ve boyutsal özellikleri mikroskop altında incelenmiştir (Şekil 2). Üretilen boncukların kurutma işlemi sonunda küreselliklerini kaybettiği ve içeriye doğru çökmeler gösterdiği belirlenmiştir. Keza, daha önceki çalı̧̧malarda da kurutmayla birlikte kapsüllerin biçimsiz formlar aldığ ifade edilmiştir (Levic vd., 2015; Kokina vd., 2019; Gholamian vd., 2021). Merkez içerikte kullanılan aroma maddesinin oda sıcaklığında katı (mentol) veya sivı (benzaldehit, izoamil asetat) halde olması aljinat kapsüllerinde biçimsel olarak gözlenebilir bir fark yaratmamıştır. Mentol (kat1), limonen (sıvı) ve bitkisel yağın (orta uzunlukta trigliserid zincirine sahip, sıvı) enkapsüle edildiği bir çalışmada, partikül yapısının merkez materyalin fiziksel durumundan (katı veya sıvı) etkilenmediği gibi yağ tipinin (uçucu veya bitkisel) de partikül şeklinde farklılık oluşturmadığ 1 sonucuna varılmıştır (Leclercq vd., 2009). Küreselliğin bozulmasına kurutma esnasında kapsül yapısından düzensiz su çıkışının neden olduğu düşünülmektedir. Özellikle su içeriği yüksek boş kapsüllerde kristalize su kapsül yüzeyinde geniş por ve çatlaklar oluşturmakta; hatta kapsülün parçalanmasına sebep olabilmektedir (Kokina vd., 2019). Aroma maddesi miktarının arttırılmasıyla kapsülün su içeriği oransal olarak düşmekte ve buna bağlı yapısal deformasyon da azalmaktadır (Levic vd., 2013). Buradan hareketle aroma maddelerinin kurutma sirasında kapsül morfolojisini stabilize ettiği ve küreselliğin korunmasına yardımc1 olduğu belirtilmektedir (Levic vd., 2015; Kokina vd., 2019). Ayrıca, Chan vd. (2011) enkapsüle edilmek istenen aktif bileşenin yanında dolgu maddesi olarak nişasta kullanılmasının şekil ve yap1 stabilizasyonunun sağlanması açısından faydalı olacağını bildirmişlerdir. 

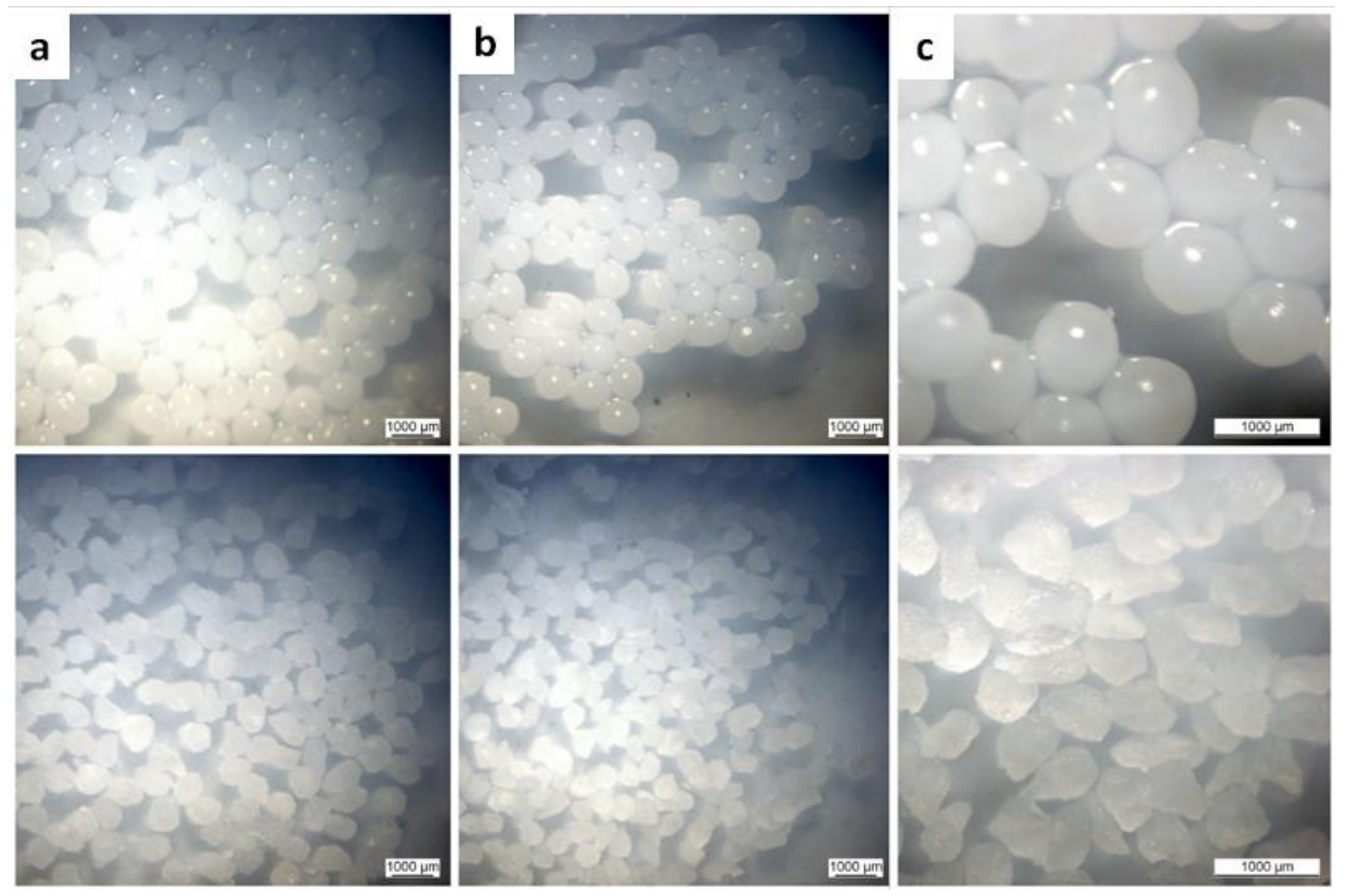

Şekil 2. Yaş (üstte) ve kuru (altta) boncuklar. a) Benzaldehit, b) İzoamil asetat, c) Mentol kapsülü

Elektrostatik ekstrüzyon yöntemi uygulanarak 8 $\mathrm{kV}$ elektrik potansiyeli altında benzaldehit, izoamil asetat ve mentol yüklü mikrokapsüller üretilmiştir. Yapılan incelemede liyofilize kapsüllerin ortalama çaplarının 668.2-846.3 $\mu \mathrm{m}$ arasında olduğu belirlenmiştir. Tüm denemeler içerisinde en düşük etkinlik değeri \%85.7 iken en yüksek \%98.5'e ulaşılmıştır (Tablo 1). Emülsiyon içerisindeki aroma maddesi miktarı arttıç̧a enkapsülasyon etkinliği düşmektedir. Enkapsülasyon etkinliği açısından, aynı aroma maddesinin farklı konsantrasyonları arasında önemli $(p<0.05)$ düzeyde bir fark olmadığı gibi; farklı aroma maddelerinin ayn konsantrasyonuna ait denemelerde de anlamlı bir fark tespit edilememiştir.

Tablo 1. Benzaldehit, izoamil asetat ve mentolün farklı konsantrasyonlardaki enkapsülasyon etkinlikleri

\begin{tabular}{|c|c|c|c|}
\hline \multirow{2}{*}{$\begin{array}{c}\text { Aroma maddesi } \\
\text { konsantrasyonu (a/a) }\end{array}$} & \multicolumn{3}{|c|}{ Enkapsülasyon etkinliği (\%) } \\
\hline & Benzaldehit & İzoamil asetat & Mentol \\
\hline$\% 10$ & $97.2 \pm 4.6^{\mathrm{a}, \mathrm{b}}$ & $98.5 \pm 3.6^{\mathrm{a}}$ & $93.4 \pm 2.1^{\mathrm{a}, \mathrm{b}}$ \\
\hline$\% 20$ & $95.2 \pm 2.6^{a, b}$ & $96.3 \pm 2.7^{\mathrm{a}, \mathrm{b}}$ & $92.1 \pm 5.2^{\mathrm{a}, \mathrm{b}}$ \\
\hline$\% 30$ & $93.7 \pm 4.2^{\mathrm{a}, \mathrm{b}}$ & $95.4 \pm 2.8^{\mathrm{a}, \mathrm{b}}$ & $91.4 \pm 4.8^{\mathrm{a}, \mathrm{b}}$ \\
\hline$\% 40$ & $90.2 \pm 3.3^{\mathrm{a}, \mathrm{b}}$ & $91.6 \pm 5.6^{\mathrm{a}, \mathrm{b}}$ & $87.6 \pm 3.6^{a, b}$ \\
\hline$\% 50$ & $88.4 \pm 2.2^{\mathrm{a}, \mathrm{b}}$ & $89.6 \pm 4.2^{\mathrm{a}, \mathrm{b}}$ & $85.7 \pm 6.1^{\mathrm{b}}$ \\
\hline
\end{tabular}

Enkapsülasyon etkinliği ile partikül çapı arasında zit bir korelasyon olduğu bilinmektedir (BelscakCvitanovic vd., 2011). Bu açıdan bakıldığında püskürtmeli kurutma daha küçük partikül boyutu sağlamasıyla dikkatleri çekmektedir. Benzaldehit açısından zengin olan badem uçucu yağı $\% 10$ oranında kullanılarak enkapsüle edildiğinde mikrokapsüllerin boyutunun çoğunlukla 1.6-31.1 $\mu \mathrm{m}$ arasında değiştiği; toplam enkapsülasyon etkinliğinin ise $\% 56$ olduğu belirlenmiştir (HoyosLeyva vd., 2019). Fesleğen uçucu yağının enkapsüle edildiği bir diğer çalışmada ise üretilen kapsüllerin partikül çapları 0.47-4.18 $\mu \mathrm{m}$; etkinlik değerleri ise \%82.3-87.2 arasında bulunmuştur
(Ozdemir vd., 2021). Başka bir çalışmada, tarçın uçucu yağı enkapsüle edilmiş ve \%84.2-93.4 arası enkapsülasyon etkinliği sağlanmıştır (Hu vd., 2020). Bu çalışmada üretilen mikrokapsüllerin daha büyük partikül çapına sahip olmasına rağmen yüksek etkinlik değerleri sergilemesinde operasyon koşullarının etkisi olduğu düşünülmektedir. Elektrostatik ekstrüzyon uygulaması oda sicaklığı koşullarında gerçekleştirilirken; kurutma aşamasında ise dondurarak kurutma yöntemi kullanılmıştır. Püskürtmeli kurutmada uygulanan yüksek işlem sıcaklığına bağlı olarak uçucu bileşenlerde kayıp yaşanabilmektedir (Sun vd., 2013). Ayrıca, çok 
küçük emülsiyon damlacıkları $(<100 \mu \mathrm{m})$, partikül oluşumu esnasında kümelenmeyi de arttırmaktadır (Leclercq vd., 2009). Püskürtmeli kurutmada üretilen kapsüllerin çok ince toz formunda olması kapsüllerin sıvı ortamlarda çözündürülmesi veya kontrollü salınım gibi spesifik işlevlerin gerçekleştirilmesinde güçlük yaratabilmektedir (Madene vd., 2006; Sun vd., 2013). Bu nedenle gida sistemlerinde kullanılması planlanan mikrokapsüllerin ne toz kadar ince olması ne de iri partiküllü olması istenmemektedir. Mentol koaservasyon yöntemiyle enkapsüle edildiği zaman partikül boyutlarının 219-325 $\mu \mathrm{m}$ arasında; enkapsülasyon etkinliğinin ise \%90'ın üzerinde olduğu belirtilmektedir (Leclercq vd., 2009). Arzu edilen partikül boyutuna ulaşılmasına rağmen mevcut çalışmaya kıyasla daha düşük enkapsülasyon etkinliği elde edilmesinde kullanılan duvar materyalinin (akasya gamı ve jelatin) etkisi olduğu düşünülmektedir.

Aljinat ve $\mathrm{CaCl}_{2}$ kullanılarak gerçekleştirilen çeşitli basit usul iyonik jelasyon çalışmalarında elde edilen kapsül boyutları $(450-2440 \mu \mathrm{m})$ ve enkapsülasyon etkinlikleri (\%49.1-85.4) oldukça geniş aralıklarda değişkenlik göstermiştir (Benavides vd., 2016; Bastos vd., 2020; Paris vd., 2020). Büyük partiküllerin yüzeylerinde genellikle daha fazla çöküntü barındırdığ 1 ve bu çöküntülerin kaplanmak istenen materyal ile dolu olduğu ifade edilmektedir. Büyük partiküllere miktar olarak daha fazla içerik yüklenirken yüzeyde kapsüllenmeden kalan kısım da artmaktadır (Jafari vd., 2007). Bu nedenle iyonik jelasyonda üretilen damlacık yapılarını biçimlendirmeye dayalı farklı ekstrüzyon teknikleri geliştirilmiştir (Saifullah vd., 2019). Çeşitli ekstrüzyon uygulamalarında partikül boyutu genellikle 200-2000 $\mu \mathrm{m}$ arasinda değişmektedir (Madene vd., 2006). Elektrostatik ekstrüzyon tekniğinde ise diğer değişkenler sabit tutulup, uygulanan elektrik potansiyeli arttırıldığında partikül çapı küçültülebilmektedir (Bugarski vd., 2006). Bu çalışmada basit usul jelasyon uygulamalarına göre daha yüksek etkinlik değerlerine ulaşılmasında uygulanan yüksek voltaja $(8 \mathrm{kV})$ bağlı nispeten daha küçük boncuklar üretilmesinin etkisi olduğu düşünülmektedir. Volic vd. (2018) $5 \mathrm{kV}$ elektrik potansiyeli altında aljinatsoya proteini kompleksi içerisinde kekik uçucu yağı enkapsüle etmişlerdir. Farklı duvar materyali bileşimine göre en küçük partikül boyutu $550 \mu \mathrm{m}$, en büyük partikül boyutu ise $1880 \mu \mathrm{m}$ olarak belirlenmiştir. Enkapsülasyon etkinliğinin ise \%72-80 arasında olduğu ifade edilmiştir. Levic vd. (2015) tarafından gerçekleştirilen çalışmada ise 6.5 $\mathrm{kV}$ potansiyel altında $d$-limonen enkapsüle edilmiştir. Partikül çapı 571-811 $\mu \mathrm{m}$ arasında değişirken, enkapsülasyon etkinliğinin \%67.1-77.3 arasında olduğu belirtilmiştir. Elektrostatik ekstrüzyonla bazı bitkisel ekstraktların enkapsülasyonuna ilişkin bir diğer çalışmada ise $7.3 \mathrm{kV}$ elektrik potansiyeli uygulanmış ve etkinlik değerleri \%80.9-89.4 arasında bulunmuştur (Belscak-Cvitanovic vd., 2011). Y1lmaztekin vd. (2019) merkez içerikte nane uçucu yağ 1 kullanarak $8 \mathrm{kV}$ elektrik potansiyeli altında aljinat boncukları üretmişlerdir. $\% 10$ ve $\% 20$ oranında uçucu yağ kullanılarak üretilen kapsüllerin partikül boyutları sirasiyla 693.5 ve $827.2 \mu \mathrm{m}$ iken; enkapsülasyon etkinlikleri ise $\% 98.4$ ve $\% 96.5$ olarak hesaplanmıştır. Özellikle son verilen örnekte, kullanılan nane uçucu yağ 1 (temel aroma bileşeni mentol) sıvı iken mevcut çalışmada kullanılan saf mentol oda sıcaklığında katı haldedir. Ancak partikül boyutu ve enkapsülasyon etkinliği açısından sonuçlar birbiriyle oldukça benzerlik göstermektedir. Elde edilen sonuçlar, yöntemin başta uçucu yağlar olmak üzere hidrofobik materyallerin enkapsülasyonunda başarıla kullanıldığına dair literatür verilerini destekler niteliktedir (Levic vd., 2015; Volic vd., 2018; Kokina vd., 2019).

\subsection{Depolama stabilitesi}

Mikroenkapsülasyon işleminin aroma maddelerinin raf ömrünü $\operatorname{arttırdığ~} 1$ çeşitli çalışmalarla ortaya konmuştur (Turasan vd., 2013; Fraj vd., 2019; Noghabi ve Molaveisi, 2020). İşlem sadece sıcaklığa karşı değil başta oksidasyon olmak üzere diğer çevresel etkilere karşı da aroma maddelerinin korunmasında oldukça etkili bir uygulamadır (Hu vd., 2020). Depolama stabilitesi kapsülün bileşimi ve fizikokimyasal özellikleri ile çevresel koşullara bağlı olarak değişkenlik gösterebilmektedir. $\mathrm{Bu}$ çalışmada aroma maddelerinin depolama stabilitelerini belirlemek üzere gündelik yaşantıda sıklıkla kullanılan sıcaklık koşulları denenmiş̧ir. Derin dondurucu ($\left.18^{\circ} \mathrm{C}\right)$, buzdolabı $\left(+4{ }^{\circ} \mathrm{C}\right)$ ve oda koşullar $1\left(+25^{\circ} \mathrm{C}\right)$ baz alınarak serbest ve enkapsüle haldeki aroma maddeleri 1ş1ksı ortamda 90 gün süreyle depolanmıştır (Şekil 3). Beklenildiği üzere gerek enkapsüle gerekse serbest aroma maddesi miktarlarında kaçınılmaz olarak azalma meydana gelmiştir. Ancak miktar açısından aynı sıcaklıkta depolanan serbest haldeki aroma maddeleri ile kapsül formları arasında önemli düzeyde $(p<0.05)$ farklılıklar oluştuğu tespit edilmiştir. Ca-aljinat kompleksinin bir bariyer gibi davranarak kapsül içerisinden aroma çıkışına engel olduğu öngörülmektedir. Depolama sıcaklığının alıkonan aroma miktarı üzerine belirgin bir etkisi olduğu tespit edilmiştir. Özellikle $-18{ }^{\circ} \mathrm{C}$ 'de depolanan 
örneklerde meydana gelen kayıp oldukça sınırlı kalmıştır. Bu sıcaklıkta 90 gün sonunda kapsül yapısında kalan benzaldehit, izoamil asetat ve mentol oranları sirasiyla $\% 92.2 \pm 3.2, \% 89.4 \pm 2.5$, $\% 94.7 \pm 3.1$ olarak bulunmuştur. Aynı koşullarda serbest formdaki aroma maddelerinde ise kalan miktarlar sirasiyla $\% 77.4 \pm 3.8, \% 75.3 \pm 4.1$ ve $\% 81.5 \pm 3.1$ olarak belirlenmiştir. Özellikle kapsüllenmiş mentolde, depolamanın ilk ve son günü arasında anlamlı $(p<0.05)$ bir kayıp olmadığ 1 sonucuna varılmıştır. Depolama sıcaklığındaki artışın aroma salınımını arttırdığı bilinmektedir (Fraj vd., 2019; Noghabi ve Molaveisi, 2020). Bu nedenle aroma maddelerinin korunmasinda mikroenkapsülasyonun etkisi yüksek depolama sıcaklıklarında daha açık görülmektedir. Sıcaklığının $25^{\circ} \mathrm{C}^{\prime}$ ye yükseltilmesiyle tüm zaman
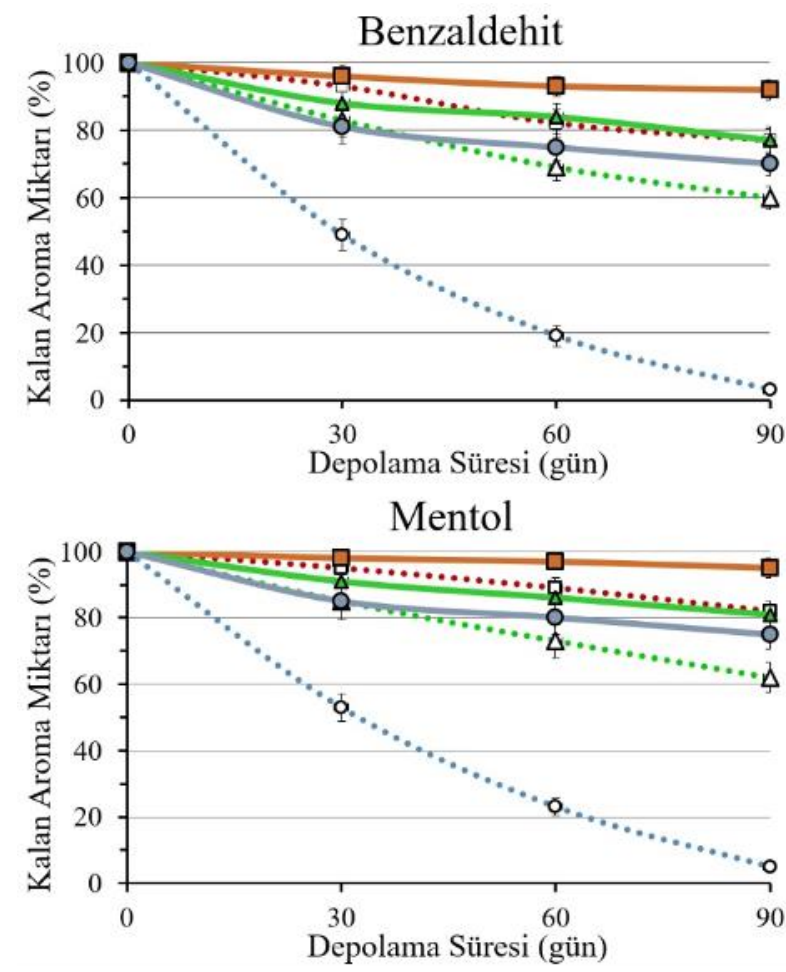

dilimlerinde serbest aroma miktarlarında önemli düzeyde $(p<0.05)$ kayıplar gözlenmiştir. 90 gün sonunda serbest haldeki izoamil asetat örneği ortamda tespit edilemezken; benzaldehitten $\% 3.0 \pm$ 0.2 , mentolden ise yalnızca $\% 4.9 \pm 0.4$ oranında kaldığı belirlenmiştir. Buna karşın $25^{\circ} \mathrm{C}$ 'de tutulan enkapsüle örnekler oldukça yüksek stabilite göstermiş ve hiçbirinde kalan aroma miktarı $\% 65$ 'in altına düşmemiştir. Depolamada hem serbest hem de kapsül formları için stabilitesi en yüksek aroma maddesi mentol olurken; en fazla kayıp izoamil asetatta yaşanmıştır. Mentolün erime noktas1 $41-43{ }^{\circ} \mathrm{C}$ arasında olup; benzaldehit ve izoamil asetattan farklı olarak oda sıcaklığında katı haldedir (Zhu vd., 2010; Sun vd., 2013). Bileşiğin buhar basıncı arttıkça depolamada meydana gelen kaybın da arttığı düşünülmektedir.

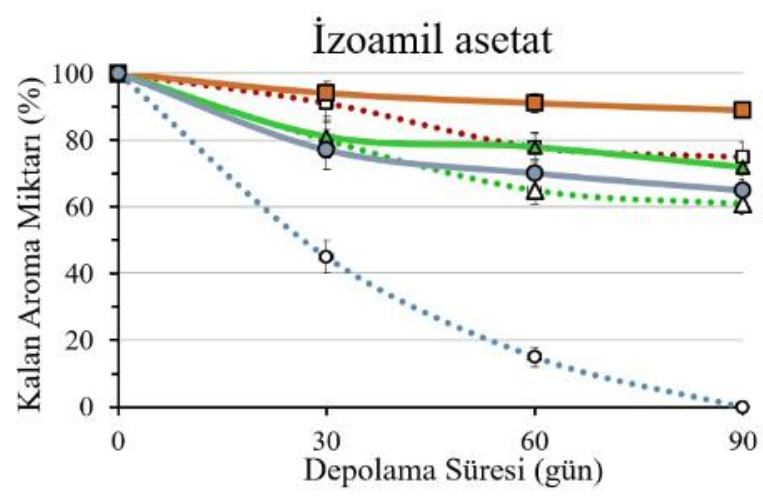

Şekil 3. Serbest ve enkapsüle aroma maddelerinin (\%10, a/a) farklı sıcaklıklardaki depolama stabiliteleri

Kaplanmıs materyalin salınım karakteristiği, duvar materyalinin yapısal özellikleriyle doğrudan ilişkilidir (Hu vd., 2020). Noghabi ve Molaveisi (2020) tarçın uçucu yağının depolama stabilitesininde kaplama materyali bileşiminin etkisini incelemek için farklı oranlarda gum Arabik, maltodekstrin ve inülin kullanmışlardır. 4 ${ }^{\circ} \mathrm{C}$ 'de 4 hafta depolanan enkapsüle yağın sinnemaldehit içeriğindeki kayıp duvar materyali bileşimine bağlı \%30.5-52.3 arasında değişmiştir. Bir başka çalışmada ise duvar materyalinde kullanilan maltodekstrinin yalnızca dekstroz eşdeğer sayısı değiştirilerek polimer yapısının etkisi değerlendirilmiştir. Uygun polimer seçimiyle
$15{ }^{\circ} \mathrm{C}$ 'de 30 gün depolanan enkapsüle biberiye yağının 1,8-sineol içeriğindeki kayıp oranı \%15'in altına düşürülmüştür (Turasan vd., 2013). Geçmiş çalışmalardan elde edilen sonuçlar, kaplama materyali çeşit ve bileşiminin salınım üzerine oldukça etkili olduğunu ortaya koymaktadır. Bunun dışında enkapsülasyonda kullanılan yöntem de kapsül yapısını etkilediğinden stabiliteyi doğrudan ilgilendirmektedir. Fraj vd. (2019) emülsifikasyon ve nano çöktürme yöntemiyle kekik uçucu yağı içeren polikaprolakton mikrokapsülleri üretmiş ve depolama sonunda iki farklı yöntemle kapsüllenen yağların karvakrol içerikleri arasında \%30'un üzerinde fark olduğunu 
tespit etmişlerdir. Kapsülün alıkoyma özelliğini etkileyen bir başka parametre ise partikül çapıdır. Enkapsülasyon çalışmalarında tekstürel ve duyusal açıdan küçük çaplı boncuklar arzu edilirken; aroma salınımının geciktirilmesinde büyük çaplı partiküller avantaj sağlamaktadır (Manojlovic vd., 2008). Büyük partiküller hacmine oranla daha küçük yüzey alanına sahiptir (Baranauskiene vd., 2007). Bu durum boncuk içerisinde alıkonan aroma maddesinin salınım süresini arttırmaktadır (Manojlovic vd., 2008). Özellikle püskürtmeli kurutma uygulamalarında operasyon koşullarına bağlı olarak çok küçük $(\leq 50 \mu \mathrm{m})$ toz partiküller elde edilmektedir (Vicente vd., 2013; Da Veiga vd., 2019). Elektrostatik ekstrüzyon uygulanan bu çalışmada ise püskürtmeli kurutmaya kıyasla daha büyük partiküller üretilmiştir. Aroma maddelerinin yüksek alıkonma oranları göstermesinde buharlaşma yüzey alanının küçük olmasının etkisi olduğu düşünülmektedir. Bunun dışında hem ekstrüzyon yöntemi hem de duvar materyali olarak aljinat kullanımı kapsüllere yüksek miktarda aroma maddesi yüklemesine olanak sağlamaktadır. Daha önce belirtildiği üzere aroma konsantrasyonunun arttırılması kapsülün su içeriğini düşürmektedir (Levic vd., 2013). Su içeriği yüksek kapsüllerde su buhar1 aroma maddelerini de beraberinde sürükleyerek bileşen kaybını arttırmaktadır (Manojlovic vd., 2008). Aljinat polimerleri arasında kalan suyun bir diğer zararı ise dondurarak kurutma esnasında boncuk yüzeyinde por oluşmasına neden olmasıdır (Gholamian vd., 2021). Kapsül yüzeyinde por sayısının az olmasının aroma maddelerinin salınımını geciktirerek kapsüllerin raf ömrünü arttırabileceği belirtilmektedir (Hu vd., 2020). Ekstrüzyonla üretilen kapsüller yüzeylerinde püskürtmeli kurutma ile üretilenlere göre genellikle daha az por içermektedir (Saifullah vd., 2019). Uzun depolama süresine rağmen çalışmada üretilen kapsüllerde aroma alıkonma oranlarının yüksek olmasında belirtilen durumların etkili olduğu düşünülmektedir.

\section{Sonuç}

$\mathrm{Bu}$ çalışmada elektrostatik ekstrüzyon yöntemi kullanılarak farklı konsantrasyonlarda benzaldehit, izoamil asetat ve mentol enkapsüle edilmiştir. $8 \mathrm{kV}$ elektrostatik potansiyel altında ortalama çapları 668.2-846.3 $\mu \mathrm{m}$ aras1 değișen aroma maddesi yüklü boncuklar üretilmiştir. Elektrik akımı uygulaması basit usul iyonik jelasyon uygulamalarına kıyasla daha küçük çaplı boncuk üretimine olanak sağlamaktadır. Liyofilizasyon sonrası boncuk küreselliğinde deformasyon gözlenmiş olmasına rağmen enkapsülasyon etkinliklerinin benzer çalışmalara kıyasla daha yüksek olduğu belirlenmiştir. Emülsiyon içerisinde $\% 50$ konsantrasyona kadar aroma maddesi kullanımı enkapsülasyon etkinliğinde anlamlı bir düşüşe neden olmamıştır. Yöntemin yoğun miktarda aroma yüklü kapsül üretimine elverişli olduğu sonucuna varılmıştır. 90 günlük depolama süresi sonunda enkapsüle aroma maddesi miktarındaki düşüş oldukça sınırlıyken; serbest aroma maddelerinde önemli düzeyde kayıp gerçekleştiği tespit edilmiştir. Düşük sıcaklıkta depolama, kapsül içeriğinin korunması açısından daha etkin sonuç vermektedir. Sonuçlar aroma maddelerinin raf ömrünün uzatılmasında uygulanan mikroenkapsülasyon işleminin oldukça etkili olduğunu göstermektedir. Gerek etkinlik gerekse depolama stabilitesi dikkate alındığında aroma maddelerinin enkapsülasyonunda elektrostatik ekstrüzyon yönteminin önemli bir potansiyele sahip olduğu düşünülmektedir. Sonraki çalışmalarda bu yöntemle üretilen aroma kapsüllerinin farklı gıda sistemleri içerisinde denenerek; çözünürlük, stabilite ve salınım özelliklerinin incelenmesi gerektiği tavsiye edilmektedir.

\section{Teşekkür}

Bu çalışmayı, 2016/07 (Güd.) proje numarası ile maddi olarak destekleyen İnönü Üniversitesi Bilimsel Araştırma Projeleri Birimi'ne teşekkür ederiz.

\section{Kaynaklar}

Balanc, B., Kalusevic, A., Drvenica, I., Coelho, M. T., Djordjevic, V., Alves, V. D., Sousa, I., MoldaoMartins, M., Rakic, V., Nedovic, V. and Bugarski, B. (2016). Calcium-alginate-inulin microbeads as carriers for aqueous carqueja extract. Journal of Food Science, 81(1), E65E75. https://doi.org/10.1111/1750-3841.13167

Baranauskiene, R., Bylaite, E., Zukauskaite, J. and Venskutonis R.P. (2007). Flavor retention of peppermint (Mentha piperita L.) essential oil spray-dried in modified starches during encapsulation and storage. Journal of Agricultural and Food Chemistry, 55, 30273036. https://doi.org/10.1021/jf062508c

Bastos, L. P. H., Vicente, J., dos Santos C. H. C., de Carvalho, M. G. and Garcia-Rojas, E. E. (2020). Encapsulation of black pepper (Piper nigrum L.) essential oil with gelatin and sodium alginate by complex coacervation. Food Hydrocolloids, 102, 105605.

https://doi.org/10.1016/j.foodhyd.2019.105605 
Belscak-Cvitanovic, A., Stojanovic, R., Manojlovic, V., Komes, D., Cindric, I. J., Nedovic, V. and Bugarski, B. (2011). Encapsulation of polyphenolic antioxidants from medicinal plant extracts in alginate-chitosan system enhanced with ascorbic acid by electrostatic extrusion. Food Research International, 44, 1094-1101. https://doi.org/ 10.1016/j.foodres.2011.03.030

Benavides, S., Cortes, P., Parada, J. and Franco, W. (2016). Development of alginate microspheres containing thyme essential oil using ionic gelation. Food Chemistry, 204, 77-83. http://dx.doi.org/10.1016/j.foodchem.2016.02.1 04

Bugarski, B., Obradovic, B., Nedovic, V. and Goosen, M. F. A. (2006). Electrostatic droplet generation technique for cell immobilization. J. P. Shu and A. Spasic (Eds.), Finely Dispersed Systems (s. 869-886). Boca Raton FL: CRC Press.

Byun, Y., Kim, Y. T., Desai, K. G. H. and Park, H. J. (2010). Microencapsulation techniques for food flavour. A. Herrmann (Ed.), The Chemistry and Biology of Volatiles (s. 307-332). UK; West Sussex: John Wiley \& Sons Ltd. https://doi.org/10.1002/9780470669532

Chan, E. S., Wong, S. L., Lee, P. P., Lee, J. S., Ti, T. B., Zhang, Z., Poncelet, D., Ravindra, P., Phan, S. H. and Yim, Z. H. (2011). Effects of starch filler on the physical properties of lyophilized calciumalginate beads and the viability of encapsulated cells. Carbohydrate Polymers, 83(1), 225-232. https://doi.org/10.1016/j.carbpol.2010.07.044

Chenni, M., El Abed, D., Neggaz, S., Rakotomanomana, N., Fernandez, X. and Chemat, F. (2020). Solvent free microwave extraction followed by encapsulation of $O$. basilicum L. essential oil for insecticide purpose. Journal of Stored Products Research, 86, 101575. https://doi.org/10.1016/j.jspr.2020.101575

Da Veiga, R. D. S., Da Silva-Buzanello, R. A., Corso, M. P. and Canan, C. (2019). Essential oils microencapsulated obtained by spray drying: a review. Journal of Essential Oil Research, 31(6), 457-473.

https://doi.org/10.1080/10412905.2019.1612788

Fraj, A., Jaafar, F., Marti, M., Coderch, L. and Ladhari, N. (2019). A comparative study of oregano (Origanum vulgare L.) essential oil-based polycaprolactone nanocapsules/ microspheres: Preparation, physicochemical characterization, and storage stability. Industrial Crops \& Products, 140, 111669. https://doi.org/10.1016/j.indcrop.2019.111669

Gandomi, H., Abbaszadeh, S., Misaghi, A., Bokaie, S. and Noori, N. (2016). Effect of chitosan-alginate encapsulation with inulin on survival of
Lactobacillus rhamnosus GG during apple juice storage and under simulated gastrointestinal conditions. LWT - Food Science and Technology, 69, 365-371. http://dx.doi.org/10.1016/j.lwt.2016.01.064

Garcia, L. C., Tonon, R. V. and Hubinger, M. D. (2012). Effect of homogenization pressure and oil load on the emulsion properties and the oil retention of microencapsulated basil essential oil (Ocimum basilicum L.). Drying Technology, 30, 14131421.

https://doi.org/10.1080/07373937.2012.685998

Gholamian, S., Nourani, M. and Bakhshi, N. (2021). Formation and characterization of calcium alginate hydrogel beads filled with cumin seeds essential oil. Food Chemistry, 338, 128143. https://doi.org/10.1016/j.foodchem.2020.128143

Hoyos-Leyva, J. D., Bello-Perez, L. A., AgamaAcevedo, J. E., Alvarez-Ramirez, J. and Jaramillo-Echeverry, L. M. (2019). Characterization of spray drying microencapsulation of almond oil into taro starch spherical aggregates. LWT - Food Science and Technology, 101, 526-533. https://doi.org/10.1016/j.lwt.2018.11.079

Hu, Q., Li, X., Chen, F., Wan, R., Yu, C. W., Li, J., McClements, D. J. and Deng, Z. (2020). Microencapsulation of an essential oil (cinnamon oil) by spray drying: effects of wall materials and storage conditions on microcapsule properties. Journal of Food Processing and Preservation, 44, e14805. https://doi.org/10.1111/jfpp.14805

Istenic, K., Balanc, B. D., Djordjevic, V. B., Bele, M., Nedovic, V. A., Bugarski, B. M. and Ulrih, N. P. (2015). Encapsulation of resveratrol into $\mathrm{Ca}$ alginate submicron particles. Journal of Food Engineering, $\quad 167, \quad 196-203$. http://dx.doi.org/10.1016/j.jfoodeng.2015.04.00 7

Jafari, S. M., He, Y. and Bhandari, B. (2007). Role of powder particle size on the encapsulation efficiency of oils during spray drying. Drying Technology, 25, 1091-1099. https://doi.org/10.1080/07373930701397343

Jyothi, N. V. N., Prasanna, P. M., Sakarkar, S. N., Prabha, K. S., Ramaiah, P. S. and Srawan, G. Y. (2010). Microencapsulation techniques, factors influencing encapsulation efficiency. Journal of Microencapsulation, 27(3), 187-197. https://doi.org/10.3109/02652040903131301

Klokk, T. I. and Melvik, J. E. (2002). Controlling the size of alginate gel beads by use of a high electrostatic potential. Journal of Microencapsulation, 19(4), 415-424. https://doi.org/10.1080/02652040210144234 
Kokina, M., Salevic, A., Kalusevic, A., Levic, S., Pantic, M., Pljevljakusic, D., Savikin, K., Shamtsyan, M., Niksic, M. and Nedovic, M. (2019). Characterization, antioxidant and antibacterial activity of essential oils and their encapsulation into biodegradable material followed by freeze drying. Food Technology \& Biotechnology. $57(2)$, 282-289.

https://doi.org/10.17113/ftb.57.02.19.5957

Leclercq, S., Harlander, K. R. and Reineccius, G. A. (2009). Formation and characterization of microcapsules by complex coacervation with liquid or solid aroma cores. Flavour and Fragrance Journal, 24, 17-24. https://doi.org/10.1002/ffj.1911

Levic, S., Djordjevic, V., Rajic, N., Milivojevic, M., Bugarski, B., Nedovic, V. (2013). Entrapment of ethyl vanillin in calcium alginate and calcium alginate/poly(vinyl alcohol) beads. Chemical Papers, $\quad 67(2), \quad$ 221-228. https://doi.org/10.2478/s11696-012-0260-1

Levic, S., Lijakovic, I. P., Djordjevic, V., Rac, V., Rakić, V., Knudsen, T. S., Pavlovic, V, Bugarski, B. and Nedovic, V. (2015). Characterization of sodium alginate/D-limonene emulsions and respective calcium alginate/D-limonene beads produced by electrostatic extrusion. Food Hydrocolloids, $\quad 45, \quad 111-123$. http://dx.doi.org/10.1016/j.foodhyd.2014.10.001

Madene, A., Jacquot, M., Scher, J. and Desobry, S. (2006). Flavour encapsulation and controlled release - a review. International Journal of Food Science and Technology, 41, 1-21. https://doi.org/10.1111/j.1365-

2621.2005.00980.x

Manojlovic, V., Rajic, N., Djonlagic, J., Obradovic, B., Nedovic, V. and Bugarski, B. (2008). Application of electrostatic extrusion - flavour encapsulation and controlled release. Sensors, 8, 1488-1496. https://doi.org/10.3390/s8031488

Nikoo, A. M., Kadkhodaee, R., Ghorani, B., Razzaq, H. and Tucker, N. (2018). Electrospray-assisted encapsulation of caffeine in alginate microhydrogels. International Journal of Biological Macromolecules, 116, 208-216. https://doi.org/10.1016/j.ijbiomac.2018.04.167

Noghabi, M.S. and Molaveisi, M. (2020). The effect of wall formulation on storage stability and physicochemical properties of cinnamon essential oil microencapsulated by spray drying. Chemical Papers, 74, 3455-3465. https://doi.org/10.1007/s11696-020-01171-9

Ozdemir, N., Bayrak, A., Tat, B., Altay, F., Kiralan, M. and Kurt, A. (2021). Microencapsulation of basil essential oil: utilization of gum arabic/whey protein isolate/maltodextrin combinations for encapsulation efficiency and in vitro release. Journal of Food Measurement and Characterization, $\quad 15, \quad 1865-1876$. https://doi.org/10.1007/s11694-020-00771-z

Paris, M. J., Ramirez-Corona, N., Palou, E. and LopezMalo, A. (2020). Modelling release mechanisms of cinnamon (Cinnamomum zeylanicum) essential oil encapsulated in alginate beads during vapor-phase application. Journal of Food Engineering, 282, 110024. https://doi.org/10.1016/j.jfoodeng.2020.110024

Renu, R. and Zehra, F. (2015). Microencapsulation of flavours. International Journal of Basic and Applied Biology, 2 (5), 333-338.

Sahlan, M. and Rahman, M. R. (2017). Optimization of microencapsulation composition of menthol, vanillin, and benzyl acetate inside polyvinyl alcohol with coacervation method for application in perfumery. 2016 2nd Materials Research Society of Indonesia Meeting (MRS), 214, 012005. Bandung: IOP. https://doi.org/10.1088/1757899X/214/1/012005

Saifullah, M., Shishir, M. R. I., Ferdowsi, R., Rahman, M. R. T. and Vuong, Q. V. (2019). Micro and nano encapsulation, retention and controlled release of flavor and aroma compounds: a critical review. Trends in Food Science \& Technology, 8 , 230-251. https://doi.org/10.1016/j.tifs.2019.02.030

Sun, P., Zeng, M., He, Z., Qin, F. and Chen, J. (2013) Controlled release of fluidized bed-coated menthol powder with a gelatin coating. Drying Technology, 31,13-14, 1619-1626. https://doi.org/10.1080/07373937.2013.798331

Turasan, H., Sahin, S. and Sumnu, G. (2015). Encapsulation of rosemary essential oil. $L W T$. Food Science and Technology, 64, 112-119. http://dx.doi.org/10.1016/j.lwt.2015.05.036

Vicente, J., Pinto, J., Menezes, J. and Gaspar, F. (2013). Fundamental analysis of particle formation in spray drying. Powder Technology, 247, 1-7. http://dx.doi.org/10.1016/j.powtec.2013.06.038

Volic, M., Lijakovic, I. P., Djordjevic, V., Jugovic, Z.K., Pecinar, I., Dajic, Z. S., Veljovic, D., Hadnadjev, M. and Bugarski, B. (2018). Alginate/soy protein system for essential oil encapsulation with intestinal delivery. Carbohydrate Polymers, 200, 15-24. https://doi.org/10.1016/j.carbpol.2018.07.033

Yilmaztekin, M., Levic, S., Kalusevic, A., Cam, M., Bugarski, B., Rakic, V., Pavlovic, V. and Nedovic, V. (2019). Characterisation of peppermint (Mentha piperita L.) essential oil encapsulates. Journal of Microencapsulation, 
$36(2)$,

109-119.

https://doi.org/10.1080/02652048.2019.1607596

Zhu, L., Lan, H., He, B., Hong, W. and Li, J. (2010). Encapsulation of menthol in beeswax by a supercritical fluid technique. International Journal of Chemical Engineering, 608680. https://doi.org/10.1155/2010/608680

Zhu, H., Zhang, Y., Tian, J. and Chu, Z. (2018). Effect of a new shell material-Jackfruit seed starch on novel flavor microcapsules containing vanilla oil. Industrial Crops \& Products, 112, 47-52. http://dx.doi.org/10.1016/j.indcrop.2017.10.060

Zuidam N. J. and Heinrich E. (2010). Encapsulation of aroma. N. J. Zuidam and V. Nedovic (Eds.), Encapsulation Technologies for Active Food Ingredients and Food Processing (s. 127-160). New York: Springer. https://doi.org/10.1007/978-1-4419-1008-0_5 